\title{
Hasil Belajar Siswa dalam Pembelajaran Jarak Jauh pada Masa Pandemi COVID 19
}

\section{Student Learning Outcomes in Distance Learning during The COVID 19 Pandemic}

\author{
Sutangsa \\ Program Pascasarjana Universitas Subang. \\ Sutangsa@unsub.ac.id
}

\begin{abstract}
Abstrak
Tujuan dari studi ini adalah untuk mendeskripsikan hasil belajar siswa dalam pembelajaran jarak jauh dan untuk mendeskripsikan pengalaman belajar mengajar siswa, guru dan orang tua dalam pembelajaran ajarak jauh. Metode dalam penelitian ini menggunakan penelitan kualitatif dskriptif dengan strategi fenomenologi. Sumber data dalam penelitian ini adalah 22 siswa dan 3 orang guru dari sekolah yang berbeda. Pengumpulan data dilakukan dengan observasi, wawancara dan dokumentasi dengan evaluasi terhadap hasil belajar siswa. Hasil penelitian menunjukan bahwa hasil pembelajaran siswa tidak memenuhi ketuntasan klasikal, dan terdapat beberapa hambatan yang dirasakan oleh siswa, guru dan orang tua dalam pembelajaran jarak jauh diantaranya yang berkaitan dengan motivasi siwa, kesiapan guru dan partisipasi pendampingan orang tua. Implikasi dari penelitian ini sebagai masukan bagi siswa, guru, orang tua dan sekolah untuk meningkatkan kesiapan dalam penyelenggaraan pembelajaran jarak jauh untuk menunjang hasil belajar siswa.
\end{abstract}

Kata Kunci : hasil belajar, pembelajaran jarak jauh

\begin{abstract}
The purpose of this study is to describe student learning outcomes in distance learning and to describe the teaching and learning experiences of students, teachers and parents in distance learning. The method in this study is descriptive qualitative research with a phenomenological strategy. The data sources were 22 students and 3 teachers from different schools. The Data collection are by observation, interviews and documentation with evaluation of student learning outcomes. The results showed that student learning outcomes did not meet classical completeness, and there were several obstacles felt by students, teachers and parents in distance learning, including those related to student motivation, teacher readiness and parental mentoring participation. The implications of this research are as input for students, teachers and parents and schools to improve readiness in implementing distance learning to support student learning outcomes.
\end{abstract}

Keywords: learning outcomes, distance learning

\section{Pendahuluan}

Penyebaran Covid-19 membuat peraturan baru yang di buat oleh masyarakat dan harus di ikuti oleh masyarakat luas. Yang melahirkan peraturan kesehatan seperti memakai masker, sering cuci tangan, dan menjaga jarak membuat seluruh sekolah di Indonesia mewajibkan mengadakan pembelajaran jarak jauh (PJJ).

Peraturan pemerintahan Nomor 21 tahun 2020 tentang Pembatasan Sosial Berskala Besar dalam rangka Percepatan Penanganan Corona Virus Disease 2019 (Covid-19) ditetapkan pada tanggal 
31 Maret 2020. Surat Edaran No. 15 Tahun 2020 Tentang Pedoman Penyelenggaraan Belajar Dari Rumah Dalam Masa Darurat Penyebaran Corona Disease (COVID-19). Keputusan Mentri Kesehatann Nomor HK.01.07/MENKES/328 tentang Panduan Pencegahan dan Pengendalian Covid-19 di Tempat Kerja Perkantoran dan Industri dalam Mendukung Keberlangsungan Usaha pada Situasi Pandemi.

Atas dasar pemaparan regulasi yang dikeluarkan di atas, maka diputuskan bahwa pembelajaran yang dilaksanakan di Era Normal Baru harus dilaksanakan secara jarak jauh (PJJ), hal ini demi menekan penyebaran covid-19. Dengan Surat Keputusan Menteri Pendidikan dan Kebudayaan Republik Indonesia terkait Surat Edaran Nomor 4 Tahun 2020 tentang Pelaksanaan Kebijakan Pendidikan dalam Masa Darurat Penyebaran Covid-19, maka lembaga pendidikan/ sekolah menjalankan pembelajaran jarak jauh dimana siswa belajar dan guru mengajar dari rumah.

Pendidikan merupakan suatu kegiatan untuk menambah pengetahuan pribadi, termasuk meningkatkan penguasaan teori dan keterampilan, serta memutuskan dan mencapai solusi kegiatan yang berkaitan dengan pencapaian tujuan (Heidjrachman dan Husnah: 1997). Bagi masyarakat pendidikan merupakan pengajaran yang dilakukan di sekolah dan sekolah merupakan tempat terjadinya pembelajaran atau pendidikan formal, akan tetapi menurut definisi pendidikan yang diambil oleh para ahli di atas, maka dapat di definisikan bahwa pendidikan adalah proses perubahan sikap dan tingkah laku seseorang dalam usaha mendewasakan manusia melalui cara pengajaran dan pelatihan yang terjadi ketika lahir sampai dengan tutup usia atau pembelajaran sepanjang hayat.

Sistem pembelajaran akan berubah secara total akibat dari pembiasaan gaya hidup setelah terjadinya Covid-19, yakni anak-anak harus melakukan segala aktifitas belajarnya dari rumah. Keseharian kegiatan di sekolah seperti bertemu guru, bermain bersama teman-teman, dan melakukan kegiatan belajar bersama-sama selalu di lakukan siswa setiap harinya, akan menyebabkan perubahan dan mengundang pertanyaan besar bagi anak-anak mengenai perubahan aktivitas dalam keseharian.

Dengan demikian, dunia akan memasuki fase baru yakni fase new normal. Fase ini akan menekankan perubahan besar dalam kegiatan sehari-hari, dalam berbagai aspek seperti ekonomi, sosial, termasuk pendidikan. Keberlangsungan masa depan generasi penerus bangsa tergantung pada pendidikan yang sedang berlangsung.

Di masa era new normal ini khususnya pada bidang pendidikan telah terjadi pro dan konra, dimana salah satu pihak dengan tegas dan semangat bahwa sekolah harus dibuka kembali untuk menghindari ketinggalan dalam berbagai aspek pembelajaran. Pihak lain menyatakan bahwa pembukaan sekolah akan berdampak buruk bagi penyebaran covid-19 dan anak-anak akan menjadi korbannya.

Kedua pemikiran diatas sangat bertolak belakang namun sama-sama memiliki titik permasalah yang serupa, yakni Old Normal Paradigma. Pemikiran ini cenderung mereduksi makna pendidikan yang hanya sebatas konteks administrasi dalam penyelenggaraan sekolah regular. School From Home and Study From Home menegaskan ada beberapa fator yang dapat mempengaruhi efektifitas belajar jika dikaitkan dengan konsep perkembangan psikologi peserta didik diantaranya meliputi peran guru, peran orang tua dan lingkungan pembelajaran.

Dalam pelaksanaan pembelajaran jarak jauh ini siswa dan orang tua mengalami beberapa kesulitan. Komisi Perlindungan Anak Indonesia (KPAI) sejak 16 Maret sampai dengan 9 April 2020 diketahui menerima 213 pengaduan dari orang tua dan siswa berkaitan dengan Pembelajaran Jarak Jauh (Kompas, 2020). Hal-hal yang duadukan diantaran; penugasan yang dirasa terlalu berat dalam waktu yang singkat, banyaknya tugas membuat rangkuman dan menyalin buku, jam belajar dirasakan masih kaku sebagimana jam pelajaran sekolah biasanya, kouta yang terbatas, dan sebagian siswa kesulitan mengikuti ujian daring karena tidak memilik gawai sendiri. Pengaduan terbanyak bersal dari Provinsi DKI Jakarta, Jawa Barat, Jawa Tengah, dan Jawa Timur.

Proses kegiatan pembelajaran secara daring (PJJ) memberikan pengalaman belajar yang berbeda pada anak, dimana interaksi anak dengan guru dan teman berbeda dengan pembelajarn biasanya. Hal ini dapat mempengaruhi hasil belajar siswa, sebagaimana menurut Sukamdinata (2005), bahwa pendekatan kontruktivisme memiliki asumsi bahwa kenyataan itu memiliki dimensi yang jamak, interaktif dan suatu pertukaran pengalaman sosial yang di interprestasikan oleh setiap individu.

Pendekatan konstruktivisme sosial yang dikembangkan oleh Vigotsky (dalam Santrock, 2014) menggambarkan bagaimana pikiran sebagai entitas, diyakini tersebar dalam lingkungan sosial, dimana pemahaman dan pengetahuan anak berkembang dari hubungan sosial. Aktivitas belajar anak dipengaruhi oleh interaksinya dengan lingkungan sekitarnya, dukungan orang tua, bimbingan guru dan 
teman sebaya yang lebih mahir. Semakin tepat peran guru dan orang tua dalam mendukung aktivitas belajarnya akan semakin mendukung kemampuan belajarnya.

Di sekolah, salah satu indikator kemamuan belajar siswa diketahui melalui tes hasil belajar. Hasil belajar adalah kemampuan-kemampuan siswa yang dimilikinya setelah ia menerima pengalaman belajar (Sudrajat, dalam Asih 2020). Dalam pemberian nilai, melalui poses penentuan nilai obyekti dengan kriteria tertentu. Hasil belajar adalah unsur ketiga dalam aktivitas belajar mengajar setelah ditentukan tujuan pembelajarn dan aktivitas belajar mengajar.

Salah satu aspek penting terhadap perkembangan peserta didik adalah ranah kognitif (pengetahuan) dan saling berkaitan dengan proses pembelajaran yang merupakan pacuan keberhasilan pembelajaran di sekolah. Menurut Myers (dalam Desmita, 2005) "Cognition refers to all the mental activities associated with thinking, ,knowing, and remmemberin". Desmita menambahkan pendapat Matilin yang menyebutkan bahwa "cognition, or mental activity, involves the acquisition, storage, retrieval, and use of knowlage".

Dari kutipan di atas, diketahui bahwa aspek kognitif adalah pemikiran yang digunakan sebagai istilah oleh para ahli untuk menjelaskan pemahaman seseorang dan aktivitas mental yang memiliki hubungan dan keterkaitan dengan persepsi, pengolahan informasi, ingatan, dan pikiran yang dapat memberikan seseorang memperoleh pengetahuan, merencanakan masa depannya, dan dalam memecahkan permasalahan, dan berkesinambungan dengan proses psikologis dalam keterkaitan dengan bagaimana individu mempelajari serta membayangkan, memperkirakan, menganalisis, memberi penilaian, dan cara untuk menyesuaikan diri dengan lingkungan.

Peneliti mendapatkan informasi dari beberapa siswa dan guru wilayah Sukajadi Kecamatan Pasteur Bandung tentang kesulitan yang dialami selama pembelajaran jarak jauh. Beberapa siswa diketahui hasil belajarnya tidak memenuhi nilai KKM pada masa pembelajaran jarak jauh ini. Dalam penelitian ini, peneliti ingin mendeskripsikan hasil belajar siswa dalam pembelajaran jarak jauh dan mendeskripsikan pengalaman belajar mengajar siswa, guru dan orang tua dalam pembelajaran jarak jauh di wilayah Sukajadi Kecamatan Pateur Bandung di masa pandemi covid 19 ini.

\section{Metode Penelitian}

Peneliti mempertimbangkan pendapat dari Sugiono (2010) yang menyatakan bahwa di dalam suatu wilayah terdapat objek atau subjek yang memiliki kualitas dan karakteristik yang ditentukan oleh observer untuk melakukan penelitian yang dapat ditarik kesimpulan. Maka dari itu, sumber informasi dalam penelitian ini adalaha 22 siswa dari 3 sekolah yang tersebar di area wilayah Sukajadi Kecamatan Pasteur Bandung, dan 3 orang guru. Data kualitatif diperoleh melalui hasil wawancara, observasi, dan studi dokumentasi yang salah satunya berupa hasil dari evaluasi kognitif (pengetahuan) yang dihitung rata rata, ketuntasan individu, dan ketuntasan klasikal. Data ini diambil pada saat proses pembelajaran yang terdapat pada Tema 3 Kelas 2.

Untuk mengetahui hasil belajar siswa, utamanya pada aspek kognitif, peneliti menggunakan tes sesuai dengan bahan ajar yang terdapat pada Tema 3 kelas 2 Tahun ajaran 2020-2021. Penulis menyiapkan instrument evaluasi kognitif (pengetahuan) siswa terhadap materi pembelajaran dalam pembelajaran tematik, khususnya diadakan pada peserta didik jenjang sekolah dasar kelas 2 yang terdapat pada Tema 3, evaluasi pembelajaran 1 hingga 6. Instrumen evaluasi ini merupakan bentuk evaluasi harian yang rutin dilaksanakan oleh guru pada setiap akhir dari sub tema pembelajaran. Instrumen evaluasi kognitif (pengetahuan) ini, dapat mengukur sejauh mana pemahaman siswa di dalam menguasai materi pembelajaran yang dilaksanakan selama BDR (Belajar dari Rumah)

Ketuntasan individu diketahui dengan menggunakan skor yang diperoleh siswa secara individu digunakan rumus yang diadaptasi dari Abidin (2016) sebagai berikut:

$$
\text { Nilai Akhir }=\frac{\text { Skor Diperoleh }}{\text { Skor Maksimal }} \times 100 \text {, }
$$

Penafsiran Sangat Baik apabila memperoleh skor 80-100, Baik apabila memperoleh skor 70-79, Cukup apabila memperoleh skor 60-69, dan Kurang apabila memperoleh skor kurang dari 60. 
Untuk enghitung nilai rata-rata kelas menurut Arikunto (2012) yaitu "Untuk mencari nilai ratarata, tinggal menjumlahkan semua skor, kemudian dibagi dengan banyaknya siswa yang memiliki skor itu". Rumus yang digunakan adalah sebagai berikut:

\section{Dimana:}

$$
\mathrm{X}=\sum \mathrm{X} / \mathrm{N}
$$

$$
\begin{aligned}
& \mathrm{X}=\text { Mean atau nilai rata-rata/ rata-rata, } \\
& \sum_{\mathrm{N}} \mathrm{X}=\text { Jumlah skor keseluruhan/ jumlah keseluruhan nilai siswa, dan } \\
& \quad \text { Banyaknya sampel/jumlah siswa. }
\end{aligned}
$$

Menghitung ketuntasan klasikal dapat memberikan gambaran ketuntasan yang telah dilakukan. Dijelaskan Depdikbud (dalam Khotimah. 2016) bahwa "Suatu kelas dikatakan tuntas belajarnya (ketuntasan klasikal) jika dalam kelas tersebut terdapat 85\% siswa yang tuntas belajarnya". Jika $<85 \%$ siswa memenuhi KKM (Kriteria Ketuntaan Minimal) maka ketuntasan klasikal tidak terpenuhi.

Untuk mengungkap pengalaman belajar mengajar siswa, guru dan orang tua dalam pembelajaran jarak jauh mempengaruhi hasil belajar siswa, peneliti mengumpulkan data dari 3 guru pada 3 sekolah di wilayah Sukajadi melalui wawancara dan observasi terstruktur terkait aktivitas mengajar guru dan belajar siswa selama Pembelajaran Jarak jauh menurut guru. Dalam wawancara ini, peneliti membuat penilaian terstruktur agara dapat mendeskripsikannya.

Data kualitatif yang diperoleh dari data hasil wawancara dan observasi aktivitas siswa dalam pembelajaran yang diplah dengan menggunakan skala. Penggunaan skala menurut Sugiono (2010) melalui pemberian skor atau rating scale, dengan acuan pemberian skor sebagai berikut : kurang (1), sedang (2), baik (3), dan sangat baik (4). Lembar observasi digunakan untuk melihat sejauh mana keterlaksanaan pembelajaran antara guru dan siswa. Menurut Purwanto (2008), pengelolaan lembar observasi ini dilakukan sebagai berikut

$\%$ Tahapan muncul $=\frac{\text { Jumlah tahapan yang muncul }}{\text { Jumlah total tahapan yang diharapkan }} \times 100$ berdasarkan maka kriteria

Penilaian hasil observasi menurt Purwanto (2002) adalah sebagai berikut : 81-100 sangat baik, 61-80 baik, 41-60 cukup, 21-40 kurang, 0-20 sangat kurang.

\section{Hasil Penelitian}

Dari tes hasil belajar Tema 3 kelas 2 Tahun ajaran 2020-2021, diketahui nilai yang diperoleh 22 siswa dari rentang 20 sampai dengan 80. Rata-rata yang diperoleh adalah 55,45. Gambaran nilai berdasarkan keterpenuhan KKM adalah sebagai berikut:

Tabel 1 Ketuntasan Klasikal

\begin{tabular}{lll}
\hline Kategori & Jumlah & Persentase \\
\hline Memenuhi KKM & 8 & $36,4 \%$ \\
Tidak Memenuhi KKM & 14 & $63,6 \%$ \\
\hline Total & 22 & $100 \%$ \\
\hline
\end{tabular}

Dari Tabel 1 dan gambar 1 diketahui bahwa sebanyak 36,4\% siswa memenuhi KKM dan 63,6\% siswa tidak memenuhi KKM. Hal ini menujukkan bahwa belum memenuhi ketuntasan klasikal. Hal ini berdasarkan ketentuan Depdikbud (dalam Khotimah. 2016: 65) bahwa "Suatu kelas dikatakan tuntas belajarnya (ketuntasan klasikal) jika dalam kelas tersebut terdapat 85\% siswa yang tuntas belajarnya". Jika $<85 \%$ siswa memenuhi KKM (Kriteria Ketuntaan Minimal) maka ketuntasan klasikal tidak terpenuhi. 


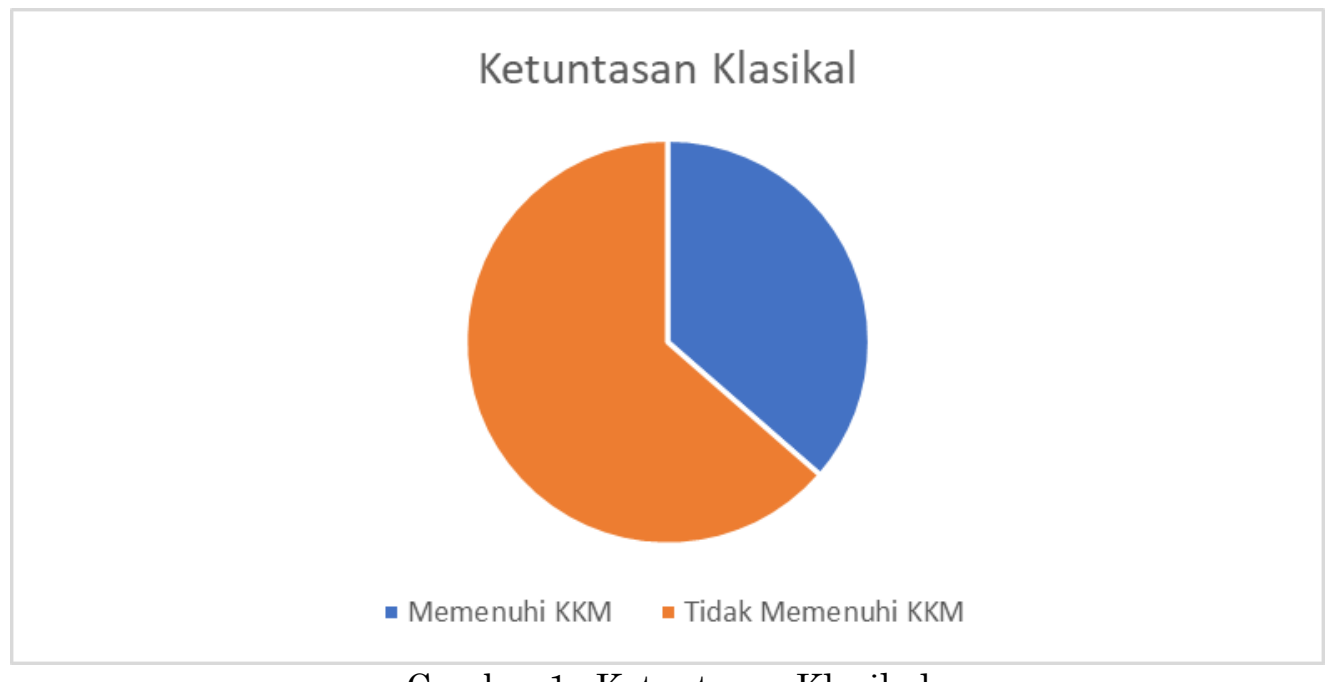

Gambar 1 . Ketuntasan Klasikal

Dalam rangka mengungkap pengalaman belajar secara daring atau pembelajaran arah jauh, peneliti menggali informasi pengalaman belajar mengajar dari siswa dan guru. Pengalaman siswa berkaitan dengan pengalaman belajarnya yang meliputi keteraturan/ kedisiplinan mengikuti jadwal pelajaran, menyimak dan aktif dalam pembeljaran, tertib dalam mengunakan atribut sekolah, pengumpulan tugas, persiapan belajar, pengisian absensi secara jujur dan teratur, pengerjaan tugas secara mandiri, menyimpan materi/ media pelajaran dari guru, mengulang pelajaan, mengikuti tambahan pelajaran dan perasaan senang ketika belajar. Dari klasifikasi yang dibuat oleh peneliti, diperoleh gambaran pembelajaran siswa sebagai berikut:

Tabel 2 Pembelajaran Siswa dalam PJJ

\begin{tabular}{|c|c|c|}
\hline Kategori & Jumlah & Persentase \\
\hline Baik Sekali & 0 & \\
\hline Baik & 4 & $1,8 \%$ \\
\hline Cukup & 8 & $3,6 \%$ \\
\hline Kurang & 10 & $45,6 \%$ \\
\hline Total & 22 & $100 \%$ \\
\hline
\end{tabular}

Dari tabel 2 dan gambar 2 diketahui bahwa sebagian besar siswa kurang optimal melakukan aktivitas belajar dalam pembelajaran jarak jauh (18,1\%), kategori cukup 36,3\% dan kategori baik 45,6\%. Tidak ada siswa yang berada pada kategori baik sekali. 


\section{Pembelajaran Siswa dalam PJJ}

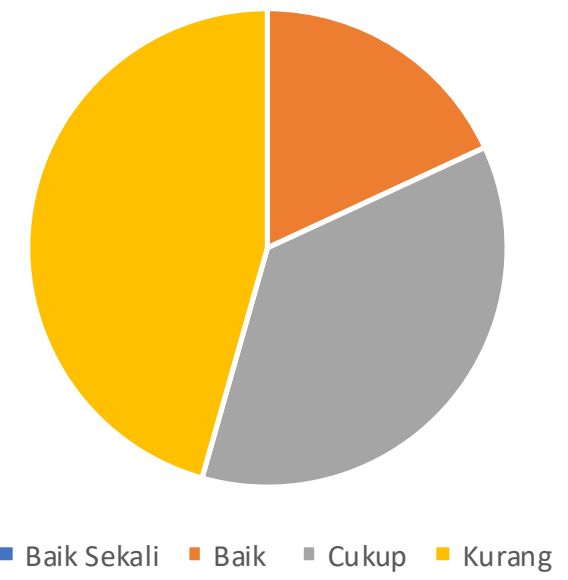

Gambar 2. Pembelajaran Siswa dalam PJJ

Berkaitan dengan pengalaman mengajar 3 guru selama pembelajaran jarak jauh, melalui observasi dan wawancara, peneliti mengungkapkan beberapa hal, diantaranya kesiapan media pada setiap materi, penggunanaan tema dan AKI dalam materi, penggunaan googlemeet, pelaksanaan evaluasi pembelajaran, RPP, perasaan senang dalam mengajar, penelusuran referensi dari internet, berkomunikasi melalui wa secara personal pada siswa, memaksimalkan teknologi dan informasi, penggunaan aplikasi pendukung seperti googleclassroom, googleform, memberikan pengarahan pada orang tua, dan melakukan tatap muka luring. Dari data dengan klasifikasi yang dibuat oleh peneliti, diperoleh gambaran pengajaran oleh guru sebagai berikut:

Tabel 3 Pengajaran Guru dalam PJJ

\begin{tabular}{|c|c|c|}
\hline Kategori & Jumlah & Persentase \\
\hline Baik Sekali & 0 & $0 \%$ \\
\hline Baik & 1 & $33,3 \%$ \\
\hline Cukup & 2 & $66,7 \%$ \\
\hline Kurang & 0 & $0 \%$ \\
\hline Total & 3 & $100 \%$ \\
\hline
\end{tabular}

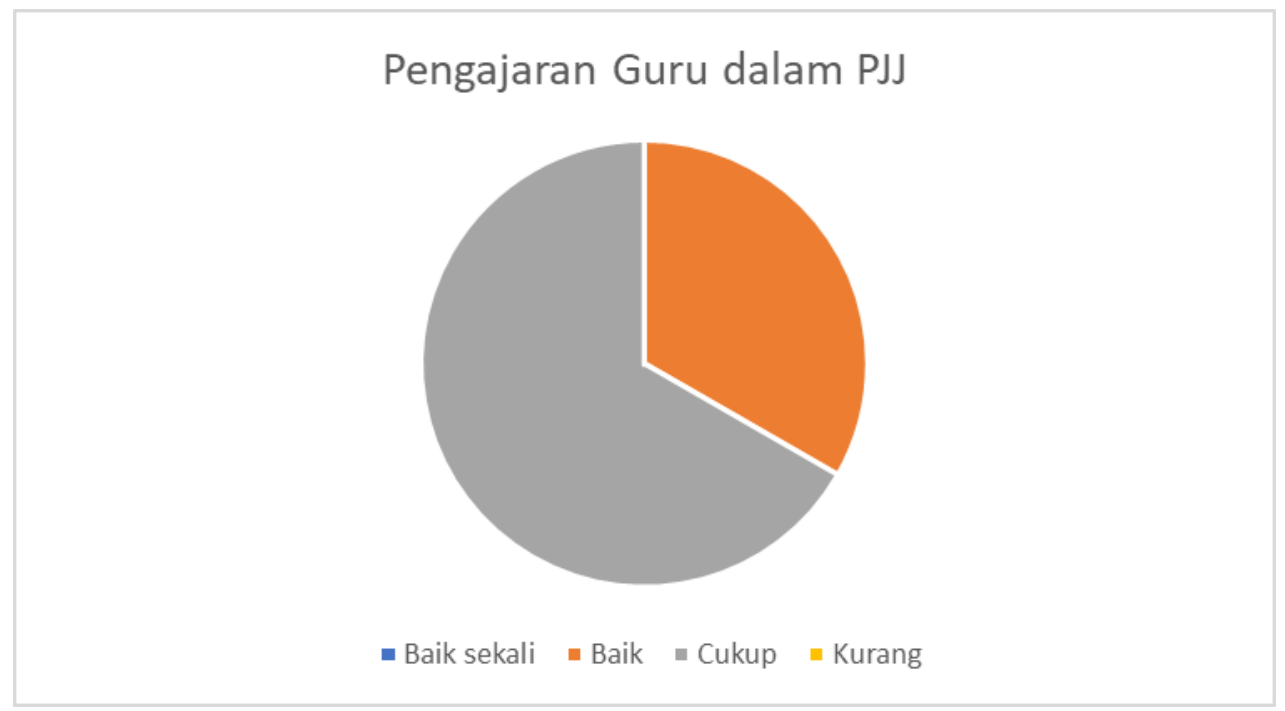

Gambar 3. Pengajaran Guru dalam PJJ 
Dari tabel 3 dan gambar 3 diketahui bahwa sebagian besar guru berada pada kategori cukup (66,7\%) dan sebagian kecil $(33,3 \%)$ pada kategori baik. Tidak ada guru dengan kategori baik sekali dan kurang dalam pengajaran selama PJJ.

Peneliti juga berupaya mengungkap partisipasi orangtua dalam pembelajaran jarak jauh ini. Beberapa hal yang diungkap adalah; Pembimbingan selama pembelajaran, pengulangan materi, penguatan pada siswa, bantuan dalam mengirim tugas harian, pembimbingan bertahap agar siswa memahami, mendukung kemandirian siswa dalam mengerjakan tugas, menggerakkan siswa disiplin mengikuti seluruh pembelajaran, perasaan senang terhadap pembelajaran jarak jauh.

Dengan pengolahan data yang kemudian dikategorisasikan berdasarkan klasifikasi yang dibuat oleh peneliti, diperoleh gambaran partisipasi pendampingan oaring tua sebagai berikut:

Hasil wawancara terhadap wali/orang tua siswa dapat diperoleh kategori Baik Sekali 0, Baik 3 orang, cukup 11 orang, dan kurang 8 orang

Tabel 4 Partisipasi Pendampingan orang Tua dalam PJJ

\begin{tabular}{ccc}
\hline Kategori & Jumlah & Persentase \\
\hline Baik Sekali & 0 & $0 \%$ \\
Baik & 3 & $13,6 \%$ \\
Cukup & 11 & $50 \%$ \\
Kurang & 8 & $36,4 \%$ \\
Total & 22 & $100 \%$ \\
\hline
\end{tabular}

\section{Partisipasi Pendampingan Orang tua dalam PJJ}

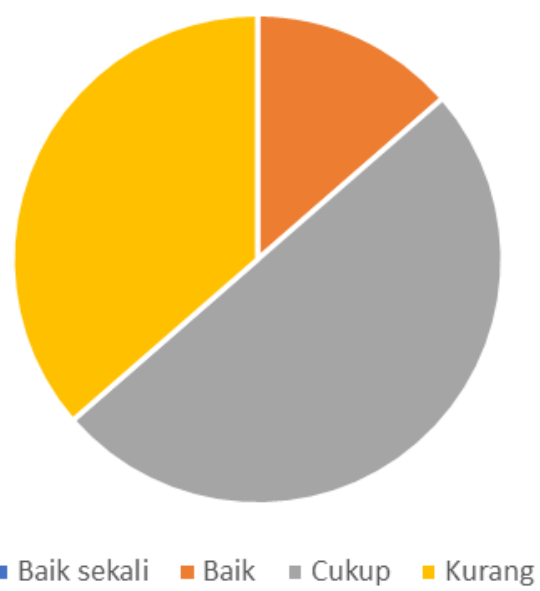

Gambar 3. Pengajaran Guru dalam PJJ

Dari tabel 4 sebagian besar partisipasi pendampingan orang tua berada pada kategori cukup 50\%, pada kategori baik $13,6 \%$ dan kategori kurang $36,4 \%$. Tidak ada partisipasi pendampingan orang pada kategori baik sekali. 


\section{Tabel 5 Temuan Esensial Proses Kognitif}

\begin{tabular}{|c|c|}
\hline Pernyataan & Temuan Esensial \\
\hline $\begin{array}{l}\text { Mengemukakan } \\
\text { pendapat selama } \\
\text { pembelajaran } \\
\text { berlangsung }\end{array}$ & $\begin{array}{l}\text { Ketika pembelajaran berlangsung, peserta didik tidak banyak mengemukakan } \\
\text { pendapatnya. Hal ini dikarenakan ketika pembelajaran jarak jauh tugas atau } \\
\text { pembelajaran yang diberikan oleh guru sebagian besar dikerjakan oleh orang tua. } \\
\text { Maka ketiika pembelajaran diadakan secara tatap muka, peserta didik tidak banyak } \\
\text { mengemukakan pendapat, serta peserta didik beradaptasi kembali untuk beani } \\
\text { mengemukakan pendapatrnya. }\end{array}$ \\
\hline \begin{tabular}{lr}
\multicolumn{3}{l}{ Mengerjakan } \\
tugas yang \\
diberikan secara \\
mandiri dan \\
sungguh-sungguh.
\end{tabular} & $\begin{array}{l}\text { Tugas yang diberikan oleh guru } 70 \% \text { diantaranya dikerjakan oleh orang tua siswa. } \\
\text { Beberapa alsan hal tersebut terjadi karena siswa banyak yang tidak menurut kepada } \\
\text { orang tua sehingga agar cepat terselesaikan orang tua sendirilah yang } \\
\text { mengerjakannya. }\end{array}$ \\
\hline $\begin{array}{l}\text { Mengerjakan tuga } \\
\text { selalu tepat } \\
\text { waktu. }\end{array}$ & lah satu penyebab keterlambatan \\
\hline $\begin{array}{l}\text { Mengajukan } \\
\text { pertanyaan setiap } \\
\text { materi } \\
\text { pembelajaran }\end{array}$ & $\begin{array}{l}\text { Pembelajaran maupun materi yang disampaikan sebagaian besar dikerjakan oleh } \\
\text { orang tua, hal ini otomatis akan berpengaruh terhadap kemampuan berpikir siswa. } \\
\text { Akibatnya siswa tidak terlalu menguasai materi pembelajaran dan tidak banyak siswa } \\
\text { yang kritis untuk bertanya seputar materi pembelajaran. }\end{array}$ \\
\hline 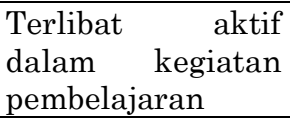 & $\begin{array}{l}\text { Karena kegiatan pembelajaran tidak setiap hari dilaksanakan secara Zoom, maka } \\
\text { tidak terlihat keaktivan siswa di dalam selama pembelajaran dalam satu minggu } \\
\text { pertemuan. Hal ini akan berakibat pada ranah psikomotor anak. }\end{array}$ \\
\hline
\end{tabular}

Untuk mengugkapkan lebih mendalam tentang pembelajaan jarak jauh ini, peneliti melakukan wawancara dan observasi lanjutan pada siswa, guru dan orang tua. Berdasarkan wawancara dan observasi terhadap siswa dan guru, diperoleh temuan sebagai berikut : Sebagian siswa sulit bangun pagi. Kesulitan bangun pagi ini karena siswa merasa tidak wajib datang ke sekolah seperti biasanya. Akibatnya, absensi siswa melalui google form dilakukan oleh orang tua. Orang tua mengungkapkan kesulitan dalam membimbing atau mendampingi anaknya pada pembelajaran jarak jauh. Kesulitan ini dirasakan karena materi dan cara belajar yang dirasakan berbeda dengan pengalaman belajar orang tua sebelunya. Hal ini menyebabkan siswa, khususnya pada jenjang kelas rendah kesulitan dalam mengerjakan tugas dari guru. Hal ini juga disebabkan siswa kelas rendah cenderung belum mandiri. Sebagain tugas dikerjakan oleh orang tua. Hal ini dilakukan oleh orang tua karena dengan kesibukannya, lebih cepat dan lebih mudah mengerjakan tugas siswa daripada mengajarinya. Orang tua jarang memberikan evaluasi/ penguatan pada siswa. Kurangnya komunikasi antara guru dan orang tua membuat orang tua merasa kesulitan dalam mendampingi atau mengajar anaknya. Beberapa siswa cenderung terlambat mengumpulkan tugas. Hal ini dirasakan karena arahan yang kurang dari orang tua sehingga siswa kurang disiplin dalam pengumpulan tugas dan banyak tugas tugas yang tidak terkerjakan. Guru mengungkapkan hambatan dalam mengajar dikarenakan kendala jaringan, dan kuota pada guru dan siswa. Hambatan yang lain yang dirasakan guru adalah ketidak pahaman orang tua pada beberpa aplikasi, penggunaan google classroom, sehingga cenderung menghambat pembelajaran. Beberapa guru merasa kesulitan dalam mengembangkan media pembalajaran utnuk pembelajran jarak jauh ini. Guru kurang aktif dalam menyelenggarakan pemberlajaran virtual sehingga interaksi siswa dan guru kurang memadai.

\section{Pembahasan}

Dari hasil penelitian tentang pengalaman belajar mengajar ini diketahui bahwa pada pengalaman belajar siswa, pengalaman mengajar guru dan partisipasi aktif orangtua, tidak ada yang berada pada kategori baik sekali. Baik siswa, guru maupun orang tua mengungkapkan beberapa kendala yang dihadapi selama pembelajaran jarak jauh yang menghambat pengajaran guru, partispasi orang tua dan pengalaman belajar siswa.

Tidak terpenuhi ketuntasan klasikal pada hasil belajar siswa khususnya pada ranah kognitif menunjukkan bahwa siswa belum maksimal dalam memahami materi pelajaran. Hal ini dikuatkan oleh hasil wawancara dan observasi lanjutan yang menunjukkan bahwa siswa cenderung kurang disiplin dalam kehadiran, pengerjaan dan pengumpulan tugas, dan peran aktif siswa dalam pembelajaran jarak 
jauh. Hal ini sejalan dengan penelitian Asih (2020) yang menujukkan bahwa pelaksanaan pembelajaran secara daring telah berpengaruh terhadap hasil belajar siswa. Siswa merasa pembelajaran daring kurang efektif karena kurang interaktif dengan guru, dan cenderung jenuh karena terpusat pada guru. Karenanya diperlukan dukungan dorongan dari guru untuk menunjang motivasi belajar siswa sehingga siswa bersemangat dan berprestasi.

Hambatan pengajaran dalam pembelajaran jarak jauh yang dialami guru diantaranya hambatan komunikasi, kendala jaringa, kesulitan dalam menggunakan aplikasi, kesulitan dalam mengembangkan media pembelajaran dan kesulitan dalam mengelola motivasi dan kedisiplinan siswa. Hasil penenitian pada hambatan mengajar dalam pembelajaran jarak jauh pada penelitian ini sejalan dengan hasil penelitian Rezky, dkk (2020) yang mengungkap problematika pembelaharan Indonesia yang dialami oelh guru diantaranya : (1) problematika dalam menyampaikan materi pelajaran, interaksi guru dengan siswa, kualitas sarana dan prasarana pembelajaran, dan penysunan perangkat pengajaran, (2) peroblematika dalam meyikapi dana tau mempersepsi watak guru dan siswa, mengembangkan kepercayaan diri siswa, dan pembinaan siswa, dan (3) problematika yang berupa keharmonisan hubungan siswa dengan siswa lainnya, pengembangan motivasi dan konsentrasi, dukunagn dalam menyimpan dan mengukur hasil belajar, dan proses bimbingan serta kebiasaan belajar siswa. Hal ini mejadi lebih kompleks dalam pembelajaran jaak jauh dikarenakan interaksi siswa dan guru sangat terbatas.

Untuk itu, guru perlu mengembangkan ketrampilan dan semangat dalam meningkakan kualitas pembelajaran jaraj jauh di masa pandemic ini. Hal ini sebagimana disampaikan Kusnandar (dalam Basar : 2021) bahwa guru yang professional haruslah menguasai bahan atau mataeri pelajaan yang kan diajarkan pada siswanya, dengan interaksi belajar mengajar dengan menyesuaikan perkembangan jaman, dengan senaniasa meningkatkan kemampuannya secara berkelanjutan, bak dari ilmu yang dimilikinya maupun pengalamannya. Hal ini juga dikuatkan oleh Asih (2020) yang menyatakan bahwa ketepatan guru dalam memilih metode pembelajaran dan peran sekolah dalam memfasilitasi media sebagai alat penyampaian materi dalam pembelajaan jarak jauh serta pelaksanaan evaluasi mendukung pembelajaran di masa pandemic covid 19.

Hasil penelitian ini juga menunjukkan bahwa patisipasi pendampingan orang tua dalam pembelajaran jarak jauh terkendala beberapa hal, diantaranya kesulitan orang tua dama membimbing/ mendampingi belajar dikarenakan materi dan cara belajar yang berbeda, komunikasi dengan guru kurang intens sehingga tidak dapat memahami dengan baik proses pembelajaran siswa, kendala orang tua dalam memootivasi dan mengarahkan kedisiplian belajar dan pengumpulan tugas, serta kendala dalam oenggunaan aplikasi pembelajaran jarak jauh. Hambatan dalam partisipasi pendampingan orang tua dalam pembelajaan jarak jauh ini turut berpengaruh pada hambatan siswa dalam memahami pelajaran yang nampak dalam ketidak terpenuhinya ketuntasan klasikal pada hasil belajar siswa.

Pentingnya dukungan orang tua ini sejalan dengan penelitian Santo dkk (2018) yang menunjukkan bahwa pengaruh dukungan orang tua terhadap prestasi belajar siswa secara signifikan. Demikian juga hasil penelitian Riska (2014) menujukkan hubungan dukungan orang tua dengan prestasi belajar siswa. Semakin besar dukungan orang tua dalam proses belajar siswa, akan semakin tinggi prestasi belajar siswa.

Untuk itu, dalam rangka mendukung aktivitas belajar siswa selama pembelajaran jarak jauh, guru dan orang tua perlu meningkatkan peran dan strateginya. Sebagaimana disampaikan oleh Vygotsky (1986) bahwa dalam proses belajar di sekolah, terdapat sistem instruksi yang kompleks bagi anak, yangperlu dissuaikan dengan perkembangan cara berpikir anak. Ketika anak terlibat dalam aktivitas yang terlalu sulit, maka orang dewasa di sekitarnya perlu memberikan dukungan atau bantuan. Dukungan ini disebut sebagai scaffolding. Maka, penting bagi guru dan sekolah untuk mengembangkan ketrampilan dan kesiapan penyelenggaraan pembelajaran jarak jauh. Orang tua juga perlu mengembangkan kemampuan untuk mengenali perkembangan siswa dan menyesuaikan dukungan dengan kemajuan siswa agar mereka dapat belajar dan berkembang dengan lebih optimal.

\section{Kesimpulan}

Hasil penelitian menunjukan bahwa hasil pembelajaran siswa diketahui bahwa sebanyak 30\% siswa memenuhi KKM dan 70\% siswa tidak memenuhi KKM, sehingga tidak memenuhi ketuntasan klasikal, karena ketuntasan individual $<85 \%$. Kedua, hasil penelitian juga menunjukkan bahwa terdapat beberapa hambatan yang dirasakan oleh siswa, guru dan orang tua dalam pembelajaran jarak jauh. 
Siswa merasa pembelajaran daring kurang efektif karena kurang berinteraksi dengan guru, dan cenderung jenuh karena pembelajaran terpusat pada guru. Hambatan pengajaran yang dialami guru dalam pembelajaran jarak jauh diantaranya adalah hambatan berkomunikasi, kendala jaringan internet, kesulitan dalam menggunakan aplikasi pembelajaran, kesulitan dalam pengembangan media pembelajaran dan kesulitan mengelola motivasi dan kedisiplinan siswa. Kendala dalam partisipasi pendampingan orang tua pada pembelajaran jarak jauh diantaranya kesulitan orang tua dalam membimbing/ mendampingi belajar yang disebabkan oleh materi dan cara belajar yang berbeda, kurang intensnya komunikasi dengan guru sehingga orang tua kesulitan memahami proses pembelajaran siswa, cara memotivasi siswa dan strategi untuk mengarahkan kedisiplian belajar dan mengumpulkan tugas, serta kendala dalam menggunakan aplikasi pembelajaran jarak jauh.

Implikasi dari penelitian ini sebagai masukan bagi siswa, guru dan orang tua dan sekolah. Hasil penelitian ini dapat dipertimbangkan dalam upaya meningkatkan kesiapan dalam penyelenggaraan pembelajaran jarak jauh untuk menunjang hasil belajar siswa. Bagi peneliti selanjutnya, hasil penelitian ini dapat dikembangkan pada penelitian-penelitian berikutnya untuk menguji hubungan antara motivasi belajar siswa, kesiapan guru, dukungan sosial orang tua, dan prestasi belajar siswa

\section{Daftar Pustaka}

Arikunto, Suharsimi. 2012. Dasar Dasar Evaluasi Pendidikan. Jakarta : Bumi Aksara.

Abidin, Yunus. 2016. Revitalisasi Penilaian Pembelajaran. Bandung : PT Refika Aditama.

Arifin, Zainal. (2014). Penelitian Pendidikan. Bandung: Remaja Rosdakarya.

Arikunto, Suharsimi. 2012. Dasar-dasar Evaluasi Pendidikan. Jakarta: Bumi Aksara.

Asih, Bety Budi, 2020, Upaya Peningkatan Hasil Belajar Siswa pada Masa Pandemi Covid-19 Di SDMU Ahmad Dahlan Braja Selebah, As-Salam I, Vol.9 No. 2.

Basar, Afip Miftahul, 2021, Problematika Pembelajaran Jarak Jauh Pada Masa Pandemi Covid-19 (Studi Kasus di SMPIT Nurul Fajri - Cikarang Barat - Bekasi), Edunesia : Jurnal Ilmiah Pendidikan, Vol 2 No 1

Berbasis Teks, Indonesia: Jurnal Pembelajaran Bahasa dan Sastra Indonesia, Vol. 1 No 1

Desmita, Psikologi Perkembangan. Bandung: Remaja Rosda Karya, 2005.

Husnan, H. d. (2011). Manajemen Psikologi : Personalia. Yogyakarta: BPFE.

Kemdikbud, pengelola web. (2020). Kemendikbud Terbitkan Pedoman Penyelenggaraan Belajar dari Rumah. Jakarta, 28 Mei 2020.

Khotimah, A. d. (2016). Hubungan antara broken home dengan sikap tantrum anak usia 4-6 tahun

kota Mojokerto. Jurnal PAUD Teratai, 236.

Moleong, L. J. (2012). Metodologi Penelitian Kualitatif. Bandung: PT Remaja Rosdakarya.

Purwanto. (2011). Metodologi Penelitian Kuantitatif. Yogyakarta: Pustaka Pelajar.

Purwanto. (2011). Psikologi Pendidikan Remaja. Bandung: PT Remaja Rosdakarya.

Rezky, Muh., Ramly, \& Saleh, Muhammad, 2020, Problematika Pembelajaran Bahasa Indonesia

Riska, 2014, Pengaruh Dukungan Orang Tua Terhadap Prestasi Belajar Siswa pada Mata Pelajaran

Sosiologi di SMA Negeri 1 Alla Kabupaten Enrekang, Jurnal Sosialisasi: Jurnal Hasil

Pemikiran, Penelitian dan Pengembangan Keilmuan, Vol 1 No 1

Santo, Zem. Kimbay, M. M., \& Werang, B. R, 2018, Pengaruh Dukungan Orang Tua Dan Motivasi Belajar Terhadap Prestasi Belajar Bahasa Indonesia Siswa SD Yppk Maria Fatimah Merauke, Magistra: Jurnal Keguruan dan Ilmu Pendidikan, Vol 5 No 2

Santrock, J.W, 2014, Psikologi Pendidikan Ed. 5 (terjemah), Salemba Humanika, Jakarta

Sugiono. 2010. Metode Penelitian Pendidikan Kuantitatif, kualitatif, dan RnD. Bandung: ALFABET.

Sukmadinata, N. S. (2014). Landasan Psikologi Proses Pendidikan. Bandung: PT Remaja Rosdakarya.

Vygotsky, L., 1986, Thought and Language, (Edited by Kozulin, A), Cambridge: The MIT Press.

https://nasional.kompas.com/read/2020/04/13/15584711/kpai-terima-213-pengaduan-pembelajaran-jarakjauh-mayoritas-keluhkan?page=all, diakses Juni 2021 